\title{
The Influence Of Capital Structure On Company Value In Manufacturing Companies Listed In Indonesia Stock Exchange
}

\author{
Nurul Hidayati Indra Ningsih ${ }^{1}$, Rangga $^{2}$ \\ ${ }_{1,2}$ Universitas Muhammadiyah Mataram \\ indraningsih21@gmail.com ${ }^{1}$, $\underline{\text { rangga.putra96.rp@ gmail.com }}^{2}$
}

\begin{abstract}
This study aims to determine: The Effect of Capital Structure on Firm Value in Manufacturing Companies Listed on the Indonesia Stock Exchange 2015-2019 Period. This type of research is a causal associative research with quantitative techniques. Total population of 183 companies, the sampling method with purposive sampling, the assilination of the selection of 39 sampling will be used. The type of data used is secondary data. The data collection technique used is documentation technique. The analysis tool uses a simple linear regression test, $t$ test, and the coefficient of determination

The results of the study are: by using the t-test hypothesis test, the variable X or DER shows the sig value $<\square$ or 0.000 <0.05). So it can be concluded that Ho is rejected and accepts Ha, meaning that the Capital Structure has a positive and significant effect on Firm Value in Manufacturing Companies on the Indonesia Stock Exchange for the period 2015-2019.
\end{abstract}

Keywords : Capital Structure, Firm Value

\section{Pengaruh Struktur Modal Terhadap Nilai Perusahaan Pada Perusahaan Manufaktur Yang Terdaftar Di Bursa Efek Indonesia}

\begin{abstract}
ABSTRAK
Penelitian ini bertujuan untuk mengetahui: Pengaruh Struktur Modal terhadap Nilai perusahaan Pada Perusahaan Manufaktur Yang Terdaftar Di Bursa Efek Indonesia Periode 2015-2019. Jenis penelitian ini adalah penelitian asosiatif kausal dengan teknik kuantitatif. Jumlah Populasi 183 perusahaan, metode sampling dengan purposive sampling, asil seleksi 39 sampling yang akan digunakan. Jenis data yang digunakan data sekunder. Teknik pengumpulan data yang digunakan adalah teknik dokumentasi. Alat analisi dengan menggunakan uji regresi linier sederhana, uji t, dan koefisien determinasi

Hasil penelitian adalah: dengan menggunakan uji hipotesis uji t, Variabel X atau DER menunjukkan nilai sig $<\alpha$ atau $0,000<0.05)$. Sehingga dapat disimpulkan $\mathrm{H}_{\mathrm{o}}$ ditolak dan menerima $\mathrm{H}_{\mathrm{a}}$, artinya Struktur Modal berpengaruh positif dan signifikan terhadap Nilai Perusahaan pada Perusahaan Manufaktur di Bursa Efek Indonesia periode tahun 2015-2019.

Kata kunci: struktur modal, nilai perusahaan
\end{abstract}




\section{PENDAHULUAN}

Saat ini kondisi perekonomian menciptakan persaingan ketat antar perusahaan manufaktur. Persaingan dalam industri ini membuat setiap perusahaan semakin meningkatkan kinerja perusahaan agar tujuannya dapat tetap tercapai. Perusahaan yang telah go public memiliki tujuan utama yaitu meningkatkan kemakmuran pemilik atau para pemegang saham melalui peningkatan nilai perusahaan. Menurut Agus Prawoto (dalam Widia, 2018:11) nilai perusahaan adalah nilai seluruh aktiva, baik aktiva berwujud yang operasional maupun bukan operasional. Jika dihubungkan dengan struktur permodalan perusahaan, nilai perusahaan berarti juga nilai dari keseluruhan susunan modal perusahaan yaitu nilai pasar wajar.

Menurut Salvatore (dalam Putri, 2016:2), Nilai perusahaan merupakan persepsi investor terhadap perusahaan, yang sering dikaitkan dengan harga saham. Harga saham yang tinggi membuat nilai perusahaan meningkat. Tujuan utama perusahaan menurut theory of the firm adalah untuk memaksimumkan kekayaan atau nilai perusahaan (value of the firm). Kekayaan pemegang saham dan perusahaan dipresentasikan oleh harga pasar dari saham yang merupakan cerminan dari keputusan investasi, pendanaan (financing), dan manajemen asset (Hermuningsih, 2013). Selain itu Investor memerlukan informasi untuk penilaian saham dalam melakukan keputusan investasi di pasar modal. Tedapat tiga jenis penilaian yang berhubungan erat dengan saham yaitu nilai pasar (market value), nilai buku (book value), dan nilai intrinsik (intrinsic value).

Nilai buku merupakan nilai saham menurut pembukuan emiten. Nilai pasar merupakan pembukuan nilai saham di pasar saham dan nilai intrinsik merupakan nilai sebenarnya dari saham (Jogiyanto, 2010:129-130). Investor perlu mengetahui dan memahami ketiga nilai tersebut sebagai informasi penting dalam pengambilan keputusan investasi saham karena dapat membantu investor untuk mengetahui saham mana yang bertumbuh dan murah. Salah satu pendekatan dalam menentukan nilai intrinsik saham adalah price book value (PBV).

Yuliningsih (dalam Christiana dan Linzzy 2017:12) menjelaskan bahwa Price to Book Value Ratio (PBV) adalah perbandingan antara harga pasar per saham dengan nilai buku per saham. Rasio PBV telah biasa digunakan untuk menilai semua jenis perusahaan karena nilai buku dapat menjadi ukuran yang rasional untuk menilai perusahaan. Begitu pula, rasio price to book valuedapat digunakan untuk memperbandingkan perusahaan- 
perusahaan yang memiliki standar akuntansi yang sama dalam suatu sektor industri. Berbeda dengan model price earning ratiohanya bisa digunakan untuk perusahaan yang menggunakan standar akuntansi yang tidak sama dalam suatu sektor industri. Bahkan, pengukuran PBV ini dapat diterapkan pada perusahaan dengan pendapatan yang negatif atau bahkan aliran kas yang negatif. Sedangkan pada price earning ratio, sering kali perusahaan memanipulasi pendapatan (net income) sebagai komponen utama Price Earning Ratio.

Perkembangan perusahaan saat ini dunia usaha tergantung pada masalah pendanaan. Sumber pendanaan di dalam perusahaan dibagi menjadi dua kategori, yaitu sumber pendanaan internal dan sumber pendanaan eksternal. Sumber pendanaan internal dapat diperoleh dari laba ditahan dan depresiasi aktiva tetap sedangkan sumber pendanaan eksternal dapat diperoleh dari para kreditur yang disebut dengan hutang.

Struktur modal merupakan gambaran dari bentuk proporsi finansial perusahaan yaitu antara modal yang dimiliki yang bersumber dari utang jangka panjang (long-term liabilities) dan modal sendiri (shareholders' equity) yang menjadi sumber pembiayaan suatu perusahaan" Fahmi (2015:184).

Manajemen keuangan harus dapat bijaksana dalam membuat keputusan struktur modal. Menurut Riyanto (dalam Tunggal dan Ngatno, 2018: 5).Struktur modal merupakan hal yang sangat penting bagi setiap perusahaan, karena baik buruknya struktur modal akan mempunyai efek yang langsung terhadap posisi keuangan perusahaan. Suatu perusahaan yang mempunyai struktur modal yang tidak baik dan mempunyai hutang yang sangat besar akan memberikan beban berat kepada perusahaan yang bersangkutan.

Dilansir dari Investor.id Perkembangan kontribusi Perusahaan-perusahaan di sub sektor Manufaktur yang Terdaftar di Bursa Efek Indonesia (2015-2019) ke PDB berfluktuatif. Pada 2015 mencapai $18,2 \%$, lalu sebesar $18,2 \%$ pada $2016,17,8 \%$ (2017), 17,63\% (2018) dan $21,64 \%$ (2019).

Untuk dapat mendukung Pertumbuhan perusahaan maka perusahaan harus dapat mengembangkan usahanya, sehingga kebutuhan pendanaan perusahaan juga mengalami peningkatan. Penenuhan kebutuhan pendanaan yang tidak sedikit menyebabkan perusahaan diharuskan mampu menetapkan struktur modal yang optimal, hal tersebut dilakukan untuk dapat menekan kemungkinan resiko keuangan yang diperoleh perusahaan dan meningkatkan nilai perusahaan dimasa yang akan datang. 


\section{TINJAUAN PUSTAKA}

\section{Struktur Modal}

Menurut Fahmi (2015:184) struktur modal adalah gambaran dari bentuk proporsi finansial perusahaan yaitu antara modal yang dimiliki yang bersumber dari utang jangka panjang (long-term liabilities) dan modal sendiri (shareholders' equity) yang menjadi sumber pembiayaan suatu perusahaan".

Teori struktur modal sebagai berikut Sianipar $(2017,4-8)$ :

a. Pendekatan Tradisional. Penganut pendekatan ini berpendapat bahwa dalam keadaan pasar modal sempurna dan tidak ada pajak,struktur modal berpengaruh terhadap nilai perusahaan (Sawir, 2004).

b. Teori Modigliani dan Miller.

1) Teori MM tanpa pajak Teori struktur modal modern yang pertama adalah teori Modigliani dan Miller (teori MM).Mereka berpendapat bahwa struktur modal tidak relevan atau tidak mempengaruhi nilai perusahaan. MM mengajukan beberapa asumsi untuk membangun teori mereka (Brigham dan Houston, 2001) yaitu:

a. Tidak terdapat agency cost.

b. Tidak ada pajak.

c. Investor dapat berhutang dengan tingkat suku bunga yang sama dengan perusahaan.

d. Investor mempunyai informasi yang sama seperti manajemen mengenai prospek perusahaan di masa depan

e. Tidak ada biaya kebangkrutan

f. Earning Before Interest and Taxes (EBIT) tidak dipengaruhi oleh penggunaan dari hutang.

g. Para investor adalah price-takers.

h. Jika terjadi kebangkrutan maka aset dapat dijual pada harga pasar (market value).

2) Teori MM dengan pajak. Teori MM tanpa pajak dianggap tidak realistis dan kemudian MM memasukkan faktor pajak ke dalam teorinya.Pajak dibayarkan kepada pemerintah, yang berarti merupakan aliran kas keluar.Hutang bisa digunakan untuk menghemat pajak,karena bunga bisa dipakai sebagai pengurang pajak. 
3) Teori Trade-Off. Menurut trade-off teory yang diungkapkan oleh Myers (2001), "Perusahaan akan berhutang sampai pada tingkat hutang tertentu, dimana penghematan pajak (tax shields) dari tambahan hutang sama dengan biaya kesulitan keuangan (financial distress)".Biaya kesulitan keuangan (Financial distress) adalah biaya kebangkrutan (bankruptcy costs) atau reorganization, dan biaya keagenan (agency costs) yang meningkat akibat dariturunnya kredibilitas suatu perusahaan. Trade-off theory dalam menentukan struktur modal yang optimal memasukkan beberapa faktor antara lain pajak, biaya keagenan (agency costs) dan biaya kesulitan keuangan (financial distress) tetapi tetap mempertahankan asumsi efisiensi pasar dan symmetric information sebagai imbangan dan manfaat penggunaan hutang. Tingkat hutang yang optimal tercapai ketika penghematan pajak (tax shields) mencapai jumlah yang maksimal terhadap biaya kesulitan keuangan (costs of financial distress). Trade-off theory mempunyai implikasi bahwa manajer akan berpikir dalam kerangka trade-off antara penghematan pajak dan biaya kesulitan keuangan dalam penentuan struktur modal.

4) Packing Order Theory. Menurut Myers (1984) pecking order theory menyatakan bahwa "Perusahaan dengan tingkat profitabilitas yang tinggi justru tingkat hutangnya rendah, dikarenakan perusahaan yang profitabilitasnya tinggi memiliki sumber dana internal yang berlimpah.” Dalam pecking order theory ini tidak terdapat struktur modal yang optimal. Secara spesifik perusahaan mempunyai urut-urutan preferensi (hierarki) dalam penggunaan dana.

5) Teori Asimetri Informasi dan Signaling Teori ini mengatakan bahwa dalam pihak pihak yang berkaitan dengan perusahaan tidak mempunyai informasi yang sama mengenai prospek dan resiko perusahaan. Pihak tertentu mempunyai informasi yang lebih dari pihak lainnya

\section{Faktor yang Mempengaruhi Struktur Modal}

Menurut Brigham dan Houston (2013:42) faktor-faktor yang perlu dipertimbangkan perusahaan ketika membuat keputusan struktur modal adalah stabilitas penjualan, struktur aktiva, leverage operasi, tingkat pertumbuhan, profitabilitas, pajak, pengendalian, sikap manajemen, sikap pemberi pinjaman dan agen pemberi peringkat, kondisi pasar, kondisi internal perusahaan, fleksibilitas keuangan. 


\section{Pengukuran Struktur Modal}

Bentuk rasio yang dipergunakan dalam struktur modal (capital structure) menurut Fahmi (dalam Eddy dan Francis 2018:4) menjelaskan tentang bentuk rumus struktur modal ini, yaitu:

a. Debt to Equity Ratio

$$
\text { Debt to Equity Ratio }=\frac{\text { Total Liabilities }}{\text { Stockholders' equity }}
$$

b. Number of Times Interest is Earned

$$
\begin{aligned}
& \text { Number of Times Interest is Earned } \\
& \qquad=\frac{\text { Income before taxes and interest expense }}{\text { Interest expense }}
\end{aligned}
$$

c. Book Value Pershare

$$
\text { Book Value Pershare }=\frac{\text { Common stockholders' equity }}{\text { Number of share of common stock outstanding }}
$$

Dalam penelitian ini penulis menggunakan indikator debt to equity ratio (DER) bertujuan untuk mengukur seberapa besar penggunaan hutang dalam menandai modal perusahaan.

\section{Nilai Perusahaan}

Nilai perusahaan merupakan persepsi investor terhadap tingkat keberhasilan perusahaan yang terkait erat dengan harga sahamnya. Harga saham yang tinggi membuat nilai perusahaan juga tinggi, dan meningkatkan kepercayaan pasar tidak hanya terhadap kinerja perusahaan saat ini namun juga pada prospek perusahaan di masa mendatang. Harga saham yang digunakan umumnya mengacu pada harga penutupan (clossing price), dan merupakan harga yang terjadi pada saat saham diperdagangkan di pasar. Nilai pasar dapat memberikan kemakmuran pemegang saham secara maksimum apabila harga saham perusahaan meningkat. Semakin tinggi nilai perusahaan, semakin besar kemakmuran yang akan diterima oleh pemilik perusahaan.

Husnan dan Pudjiastuti (dalam Sintyana dan Luh, 2019:7718-7719) mengartikan nilai perusahaan sebagai harga yang mampu dibayarkan oleh calon pembeli ketika perusahaan tersebut dijual. Perusahaan go public atau telah menawarkan saham ke publik maka nilai perusahaan diartikan sebagai persepsi seorang investor terhadap perusahaan itu sendiri. Investor dapat mempergunakan nilai perusahaan sebagai dasar untuk melihat kinerja perusahaan pada periode mendatang, dimana nilai perusahaan sering dikaitkan dengan harga 
saham. Investor akan memperoleh keuntungan apabila harga saham perusahaan tinggi.

\section{Pengukuran Nilai Perusahaan}

Menurut Sudana (2011:23), beberapa indikator yang dapat digunakan untuk mengukur nilai perusahaan antara lain:

1. Price Earning Ratio (PER) Price earning ratio menunjukkan berapa banyak jumlah uang yang rela dikeluarkan oleh para investor untuk membayar setiap dolar laba yang dilaporkan (Brigham dan Houston, 2006:110). Kegunaan price earning ratio adalah untuk melihat bagaimana pasar menghargai kinerja perusahaan yang dicerminkan oleh earning per share nya. Price earning ratio menunjukkan hubungan antara pasar saham biasa dengan earning per share.

2. Tobin's Q Alternatif lain yang digunakan dalam mengukur nilai perusahaan adalah dengan menggunakan metode Tobin's Q yang dikembangkan oleh James Tobin. Tobin's Q dihitung dengan membandingkan rasio nilai pasar saham perusahaan dengan nilai buku ekuitas perusahaan (Weston dan Copeland, 2001). Rasio Q lebih unggul daripada rasio nilai pasar terhadap nilai buku karena rasio ini fokus pada berapa nilai perusahaan saat ini secara relatif terhadap berapa biaya yang dibutuhkan untuk menggantinya saat ini.

3. Price to Book Value (PBV) Komponen penting lain yang harus diperhatikan dalam analisis kondisi perusahaan adalah Price to Book Value (PBV) yang merupakan salah satu variabel yang dipertimbangkan seorang investor dalam menentukan saham mana yang akan dibeli. Untuk perusahaan-perusahaan yang berjalan dengan baik, umumnya rasio ini mencapai diatas satu, yang menunjukkan bahwa nilai pasar saham lebih besar dari nilai bukunya. Semakin besar rasio PBV semakin tinggi perusahaan dinilai oleh para pemodal relatif dibandingkan dengan dana yang telah ditanamkan di perusahaan. Price to book value yang tinggi akan membuat pasar percaya atas prospek perusahaan kedepan. Hal itu juga yang menjadi keinginan para pemilik perusahaan, sebab nilai perusahaan yang tinggi mengindikasikan kemakmuran pemegang saham juga tinggi. Menurut (Brigham dan Houston, 2006:112), nilai perusahaan dapat dirumuskan sebagai berikut:

$$
P B V=\frac{\text { Market price per share }}{\text { Book value per share }}
$$

Dalam penelitian ini penulis menggunakan indikator dari nilai perusahaan adalah

Price Book Value (PBV). Price Book Value memiliki keunggulan yaitu nilai buku 
merupakan ukuran yang stabil dan sederhana yang dapat dibandingkan dengan harga pasar. PBV dapat dibandingkan antar perusahaan sejenis untuk menunjukkan tanda mahal/murahnya suatu saham.

\section{METODE PENELITIAN}

Jenis penelitian ini adalah penelitian asosiatif kausal dengan teknik kuantitatif. Jumlah Populasi 183 perusahaan, metode sampling dengan purposive sampling, hasil seleksi 39 sampling yang akan digunakan. Jenis data yang digunakan data sekunder. Teknik pengumpulan data yang digunakan adalah teknik dokumentasi. Alat analisi dengan menggunakan uji regresi linier sederhana, uji t, dan koefisien determinasi.

\section{HASIL DAN PEMBAHASAN}

\section{Regresi Linier Sederhana}

Tabel 1. Hasil Uji Regresi Linier Berganda

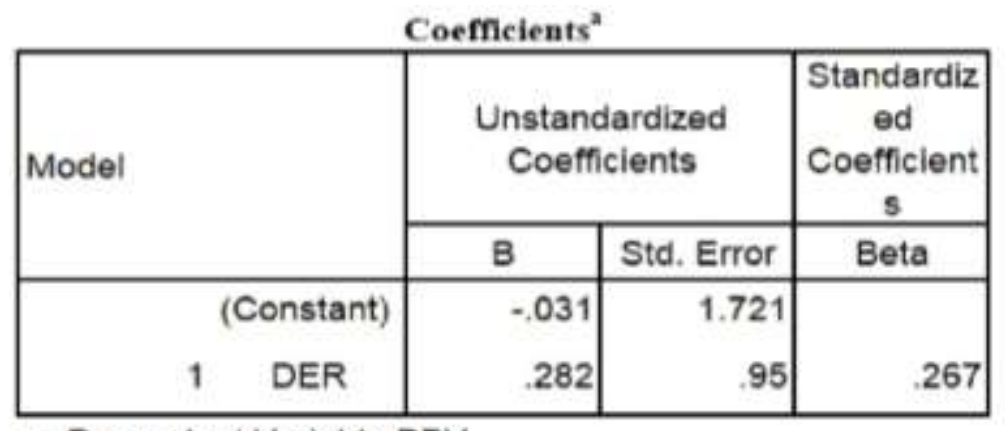

a. Dependent Variable:PBV

Sumber: Data skunder 2020 (diolah)

Berdasarkan hasil di atas diperoleh nilai konstanta pada kolom B. Sehingga dapat diperoleh persamaan regresi sebagai berikut: $\mathrm{Y}=0,282+0,267 \mathrm{X}$ atau $\mathrm{PBV}=0,282+0,267 \mathrm{DER}$ Konstanta sebesar 0,282 menyatakan bahwa jika tidak ada nilai DER maka nilai PBV sebesar 0,282. Koefisien regresi $X$ sebesar 0,267 menyatakan bahwa setiap penambahan 1 nilai DER, maka nilai PBV akan meningkat sebesar 0,267. 


\section{Uji t}

Tabel 2. Hasil Uji Parsial ( Uji t )

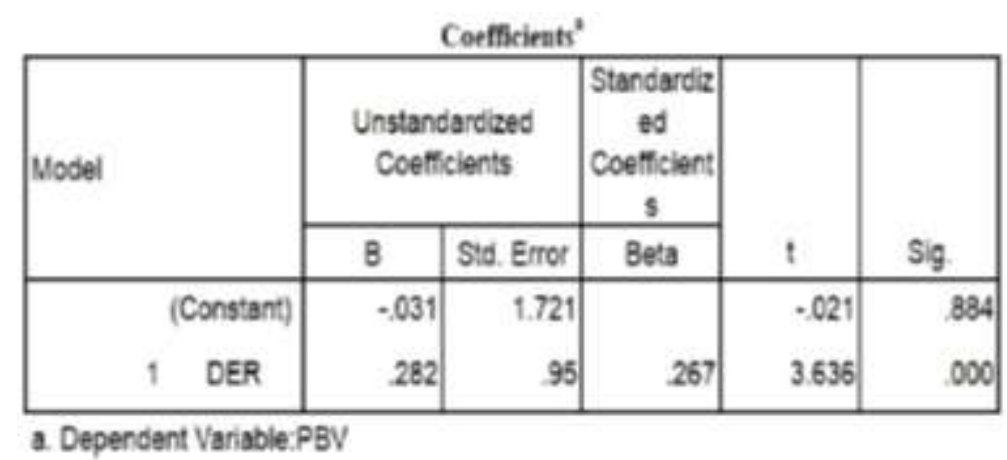

Sumber: Data skunder 2020 (diolah)

Variabel $X$ atau DER menunjukkan nilai sig $<\alpha$ atau $0,000<0.05)$. Sehingga dapat disimpulkan $\mathrm{H}_{\mathrm{o}}$ ditolak dan menerima $\mathrm{H}_{\mathrm{a}}$, artinya Struktur Modal berpengaruh positif dan signifikan terhadap Nilai Perusahaan pada Perusahaan Manufaktur di Bursa Efek Indonesia periode tahun 2015-2019.

Bagi setiap perusahaan, keputusan dalam pemilihan sumber dana merupakan hal yang sangat penting, karena hal tersebut akan mempengaruhi struktur keuangan perusahaan, yang akhirnya akan mempengaruhi kinerja keuangan perusahaan. Sumber dana perusahaan dicerminkan oleh modal asing dan modal sendiri yang diukur dengan debt to equity ratio (DER). Semakin tinggi hutang untuk membiayai operasional perusahaan maka akan menurunkan nilai perusahaan, hutang yang tinggi akan menyebabkan beban (bunga) yang akan ditanggung perusahaan juga besar.

Hasil penelitian ini menunjukkan bahwa peningkatan DER yang menunjukkan penggunaan utang perusahaan diikuti dengan peningkatan PBV yang signifikan. Ini artinya rata-rata perusahaan yang manufaktur yang terdaftar di BEI dapat mengoptimalkan penggunaan leverage-nya. Artinya struktur modal berada dibawah titik optimal. Sehingga rasio DER dalam menilai struktur modal perusahaan merupakan faktor yang dapat menjadi pertimbangan investor dalam melakukan investasi. Hal ini sesuai dengan teori Trade off Theory menjelaskan bahwa jika posisi struktur modal berada di bawah titik optimal, maka setiap hutang tambahan akan meningkatkan nilai perusahaan. Sebaliknya, jika posisi masingmasing struktur modal berada di atas titik optimal, maka hutang tambahan apa pun akan 
menurunkan nilai perusahaan. Maka dapat dikatakan bahwa struktur modal memiliki pengaruh yang positif terhadap nilai perusahaan

Hasil penelitian ini sejalan dengan penelitian yang pernah dilakukan oleh Ramdhonah (2019), yang mendapatkan hasil bahwa struktur modal berpengaruh positif terhadap nilai perusahaan Pada Perusahaan Sektor Pertambangan Yang Terdaftar Di Bursa Efek Indonesia Tahun 2011-2017.

\section{Koefisien Determinasi}

Tabel 3. Uji Koefisien Determinasi

\begin{tabular}{l|r|r|r|r|}
\hline Model & R & R Square & $\begin{array}{c}\text { Adjusted R } \\
\text { Square }\end{array}$ & $\begin{array}{c}\text { Std. Error } \\
\text { of the } \\
\text { Estimate }\end{array}$ \\
\hline 1 & $.723^{2}$ & .528 & 518 & 267.076 \\
\hline
\end{tabular}
a. Predictors: (Constant), DER
b. Dependent Variable: PBV

Sumber: Data skunder 2020 (diolah)

Berdasarkan tabel di atas diperoleh angka $\mathrm{R}^{2}$ ( $\mathrm{R}$ Square) sebesar 0,528, hal ini menunjukkan bahwa presentase pengaruh struktur modal terhadap nilai perusahaan sebesar $52,8 \%$. Sedangkan sisanya sebesar 47,2 \% dipengaruhi atau dijelaskan oleh variabel lain yang tidak dimasukkan dalam model penelitian ini.

\section{SIMPULAN}

Struktur Modal berpengaruh posititf dan signifikan terhadap Nilai Perusahaan pada Perusahaan Manufaktur di Bursa Efek Indonesia periode tahun 2015-2019. Hasil penelitian ini menunjukkan bahwa penggunaan hutang yang tinggi dapat meningkatkan nilai perusahaan, karena penggunaan hutang tersebut investor menganggap bahwa perusahaan memiliki prospek usaha yang baik di masa yang akan datang. 


\section{DAFTAR PUSTAKA}

Brigham, F. Eugene dan Joel F. Houston. (2013). Dasar-dasar Manajemen Keuangan. Jakarta: Salemba Empat.

Fahmi, Irham. (2015). Analisis Laporan Keuangan. Bandung: Alfabeta.

Jogiyanto, H. (2010). Teori Portofolio dan Analisis Investasi. Edisi Keenam. Yogyakarta: BPFE.

Sudana, Made. I. (2011). Manajemen Keuangan Perusahaan. Jakarta: Erlangga

Hermuningsih, S (2013). Pengaruh Profitabilitas, Growth Opportunity, Struktur Modal Terhadap Nilai Perusahaan Pada Perusahaan Publik di Indonesia. Lecturer at Economic Department, University of Sarjanawiyata Taman siswa Yogyakarta, Yogyakarta.

Widi Astuti Rosadi (2018). Liquidity, Leverage, And Profitability The Influence On Firm Value (Survey On Mining Firm Sub Sector Of Coal Listed In Indonesia Stock Exchange On Period 2012-2016). UNIKOM, Bandung.

Julia Putri (2016). Pengaruh Struktur Modal Terhadap Nilai Perusahaan Pada Perusahaan Manufaktur Go Publik (Studi Kasus Sektor Makanan Dan Minuman). JOM FISIP, $3(2), 1-12$.

Leonard AL Cahyoputra. (2019). Manufaktur Lemah, Jumlah Pengusaha Baru Minim. Retrieved from https://investor.id/business/manufaktur-lemah-jumlah-pengusahabaru-minim.

Tunggal, C. A., and N. Ngatno. (2018). Pengaruh Struktur Modal Terhadap Nilai Perusahaan dengan Ukuran dan Umur Perusahaan sebagai Variabel Moderator (Studi Kasus Tahun 2014- 2016) pada Perusahaan Sub-Sektor Makanan dan Minuman yang Terdaftar di BEI," Jurnal Ilmu Administrasi Bisnis,7(2), 141-157. Retrieved from http://ejournals1.undip.ac.id/index.php/

Zitri, I., Rifaid, R., \& Lestanata, Y. (2020). Implementasi Dana Desa dalam Meningkatkan Kesejahteraan Masyarakat Desa Berdasarkan Undang-Undang Nomor 6 Tahun 2014 
Tentang Desa. Journal of Governance and Local Politics (JGLP), 2(2), 164-190.

Sianipar, Syarinah. (2017). Pengaruh Struktur Modal Dan Profitabilitas Terhadap Nilai Perusahaan Pada Sektor Makanan Dan Minuman Yang Terdaftar Di Bursa Efek $\begin{array}{llll}\text { Indonesia. } & \text { Jom } & \text { FISIP, } & \text { (1) }\end{array}$ https://media.neliti.com/media/publications/124933-ID-pengaruh-struktur-modaldan-profitabilit.pdf.

Eddy Winarso dan Francis M. Hutabarat2 (2018). Hubungan Struktur Modal Dan Profitabilitas: Analisis Perusahaan Infrastruktur pada Indonesian Stock Exchange Tahun 2012-2016. Jurnal Akuntansi, 7, (2), 1-8. Doi: https://doi.org/10.46806/ja.v7i2.498

Christiana, Irma, \& Linzzy Pratami Putri. (2017). Faktor-faktor yang mempengaruhi price to book value. Jurnal Studi Akuntansi \& Keuangan, 1(1), 11-20. Doi: http://doi.org/10.5281/zenodo.1064186.

Sintyana, I Putu Hendra dan Luh Gede Sri Artini. (2019). Pengaruh Profitabilitas, Struktur Modal, Ukuran Perusahaan Dan Kebijakan Dividen Terhadap Nilai Perusahaan. EJurnal Manajemen, 8(2) Doi: https://doi.org/10.24843/EJMUNUD.2019.v8.i2.p7. 